\title{
Heart failure with preserved ejection fraction: The dark side of an old disease
}

\section{Insuficiencia cardíaca con fracción de expulsión preservada: el lado oscuro de una vieja enfermedad}

\author{
Diego Araiza-Garaygordobil', Alan Fuentes-Mendoza', Carolina Guerrero-Pando', \\ Alejandro Cabello-López², Pablo Martínez-Amezcua ${ }^{3}$, Rodrigo Gopar-Nieto', \\ Arturo I. Alonso-Vázquez ${ }^{1}$, Itzel V. Delgado-Cruz', and Alexandra Arias-Mendoza ${ }^{1 *}$ \\ ${ }^{1}$ Instituto Nacional de Cardiología Ignacio Chávez; ${ }^{2}$ Centro Médico Nacional Siglo XXI. Instituto Mexicano del Seguro Social, Mexico City, Mexico; \\ ${ }^{3}$ Johns Hopkins University, Baltimore, Maryland, USA
}

\begin{abstract}
Heart failure (HF) is a global public health problem, with more than 37 million patients living with HF around the world. HF with preserved ejection fraction (HFpEF) is an increasingly common category (approximately $60 \%$ of the cases) and shows remarkable differences in diagnosis and treatment when compared with HF with reduced EF. The current review covers epidemiology, risk factors, pathophysiologic mechanisms, clinical and paraclinical characteristics, and diagnostic criteria of HFpEF and concludes with a plea for original research in our country.
\end{abstract}

Key words: Heart failure. Preserved ejection fraction. Epidemiology. Risk factors. Physiopathological mechanisms. Clinical features. Diagnostic criteria.

\section{Resumen}

La insuficiencia cardíaca (IC) es un problema de salud pública global con más de 37 millones de individuos afectados en el mundo. La insuficiencia cardíaca con fracción de expulsión preservada (ICFEp) representa una categoría cada vez más frecuente en la práctica clínica, constituye hasta el $60 \%$ de los casos y presenta diferencias importantes en el diagnóstico y tratamiento en comparación con la insuficiencia cardíaca y la fracción de expulsión reducida. Esta revisión de ICFEp expone la epidemiología, delimita los principales factores de riesgo y mecanismos fisiopatológicos, identifica las características clínicas/paraclínicas y los criterios diagnósticos, y finaliza con un llamado para realizar investigación en este país.

Palabras clave: Insuficiencia cardíaca. Fracción de expulsión preservada. Epidemiología. Factores de riesgo. Mecanismos fisiopatológicos. Características clínicas. Criterios diagnósticos.

\section{Correspondence:}

*Alexandra Arias-Mendoza

Instituto Nacional de Cardiología Ignacio Chávez Juan Badiano 1

Col. Belisario Domínguez Sección XVI, Del. Tlalpan

C.P. 14080 , Ciudad de México, México

Date of reception: 25-03-2019

Date of acceptance: 13-05-2019

E-mail: aariasm @yahoo.com

DOI: 10.24875/ACME.M20000069
Available online: 05-08-2019 Arch Cardiol Mex (Eng). 2019;89(4):330-337 www.archivoscardiologia.com 2604-7063/@ 2019 Instituto Nacional de Cardiología Ignacio Chávez. Published by Permanyer. This is an open access article under the CC BY-NC-ND license (http://creativecommons.org/licenses/by-nc-nd/4.0/). 


\section{Introduction}

Heart failure (HF) is a global public health problem. It is the main cause of hospital admissions in adults in developed countries ${ }^{1}$. Population aging and an increase in the prevalence of non-contagious diseases (hypertension, diabetes, hypercholesterolemia, etc.) make for $\mathrm{HF}$ to be increasingly frequent in this country and in the world ${ }^{2}$.

However, HF clinical phenotype is changing. HF with preserved ejection fraction (HFpEF) represents an increasingly common category in clinical practice, and it accounts for up to $60 \%$ of cases $^{3}$. The absence of cardiomegaly, the sporadic nature of symptoms, clinical presentation often similar to that of other differential diagnoses and the high rate of false positives in biomarker results turn HFpEF into a diagnostic challenge, even in hands of the cardiology specialist. In addition, the absence of data on the epidemiology and prognosis of HFpEF in Mexican patients make for this disease to be a poorly defined problem and to represent a considerable health burden in Mexico.

This HFpEF review describes its epidemiology, delimits its main risk factors and pathophysiological mechanisms, identifies its clinical/paraclinical characteristics and diagnostic criteria, and expresses a call to the conduction of research in Mexico.

\section{HFpEF epidemiology}

HF represents a problem of global public health with $>37.7$ million individuals affected worldwide. Only in the USA, 550,000 new cases are diagnosed every year ${ }^{1,2}$.

The European Society of Cardiology Heart Failure Guidelines classify HF in three groups according to $\mathrm{EF}^{3,4}$ : HF with preserved $\mathrm{EF}$ (HFpEF), characterized by an $\mathrm{EF}>50 \%$; HF with borderline $\mathrm{EF}$ or intermediate interval, characterized by an EF of $40-49 \%$ (HFbEF); and $\mathrm{HF}$ with reduced $\mathrm{EF}$, recognizable by an $\mathrm{EF}<40 \%{ }^{3}$ (HFrEF) (Table 1). Epidemiological studies indicate that more than half the patients with HF have preserved EF, and this proportion continues on the rise ${ }^{5}$. The increased incidence of this entity is mainly due to the increase in life expectancy and a higher prevalence of risk factors such as hypertension and diabetes, with a flattening of the rate of hospitalizations due to HFrEF and a higher number of hospitalizations associated with $\mathrm{HFpEF}^{6}$.

Notwithstanding, information on HFpEF epidemiology and prognosis is scarce in Latin America. A recent meta-analysis that included mostly studies from South America showed a similar incidence to that reported in
North American studies, with a rate of 310 cases/100,000 patients/year, and a prevalence of $1.01 \%^{7}$. However, data on HFpEF are sparse, since most studies include especially patients with reduced EF.

A Mexican study by Méndez et al. pointed out that up to $33 \%$ of patients had preserved EF and recorded an overall mortality (HFrEF and HFpEF) of $11 \%$ at 1 year ${ }^{8}$. A systematic review by Bocchi et al. found variable data regarding prevalence, ranging from $0 \%$ to $37 \%$ in patients followed on an outpatient basis and from $20 \%$ to $45.7 \%$ in hospitalized individuals ${ }^{9}$.

Patients with HF and preserved EF show epidemiological differences in comparison with subjects with reduced $\mathrm{EF}^{10,11}$. Usually, they are older, females in a larger proportion and there is a higher prevalence of hypertension, ventricular hypertrophy, and atrial fibrillation. A history of myocardial infarction is less common, while there are no significant differences regarding the frequency of diabetes or kidney failure. Neither are there differences with regard to clinical presentation, although, in some studies, patients with HFpEF have been observed to have a better baseline performance status and a better perception of their own quality of life ${ }^{12}$. However, the rate of hospital readmissions and health global $\cos ^{13}$ is similar to those associated with $\mathrm{HF}$ with reduced $\mathrm{EF}$.

There is controversy about HFrEF mortality rates, given that some studies show that patients with HFrEF have a lower risk of cardiovascular death than patients with $\mathrm{HFpEF}^{14,15}$, while others indicate otherwise. However, all-cause mortality continues to be high in patients with HFpEF, with a rate of $121 / 1000$ patient-years in comparison with $141 / 1000$ patient-years in the HFrEF group ${ }^{16}$.

Tribouilloy et al. documented a survival rate of $43 \%$ 5 years after a first episode of hospitalization in patients with $\mathrm{HFpEF}$, which was not different in patients with reduced EF (43 vs. $46 \% ; p=0.95)^{17}$. Shah et al., in a cohort of 39,982 Medicare patients in the US, published that 5-year mortality for HFrEF was slightly lower (71.3\%) in comparison with HFbEF (75.7\%) and HFpEF (75.7\%), as well as rehospitalization rates, which were slightly lower in the HFrEF group (82.2\%) in comparison with those in the HFpEF group (84\%) 1 .

In view of the above, and despite the variability of mortality rates in different studies, the growing health problem that HF represents is confirmed, with mortality rates in all three EF categories being similar.

\section{HFpEF pathophysiology}

HFpEF pathophysiological mechanisms are an area of growing interest in cardiology. While early research 
Table 1. Heart failure classification according to the left ventricle ejection fraction ${ }^{1}$

\begin{tabular}{|l|l|l|l|l|}
\hline & & HFrEF & HFbEF & HFpEF \\
\hline Criteria & 1 & Signs and/or symptoms & Signs and/or symptoms & Signs and/or symptoms \\
\hline 2 & LVEF $<40 \%$ & LVEF $40-49 \%$ & LVEF $\geq 50 \%$ \\
\hline 3 & - & $\begin{array}{l}\text { 1. High natriuretic peptide values* } \\
\text { 2. At least one additional criterion: } \\
\text { a. Relevant structural heart disease } \\
\text { (LVH/LA dilation) } \\
\text { b. Diastolic dysfunction (see above) }\end{array}$ & $\begin{array}{l}\text { 1. High natriuretic peptide values* } \\
\text { 2. At least one additional criterion: } \\
\text { a. Relevant structural heart disease } \\
\text { (LVH/LA dilation) }\end{array}$ \\
\hline b. Diastolic dysfunction (see above)
\end{tabular}

${ }^{*} \mathrm{BNP} \geq 35 \mathrm{pg} / \mathrm{mL}$ and/or NT-proBNP $\geq 125 \mathrm{pg} / \mathrm{mL}$.

\section{Heart failure with preserved ejection fraction}

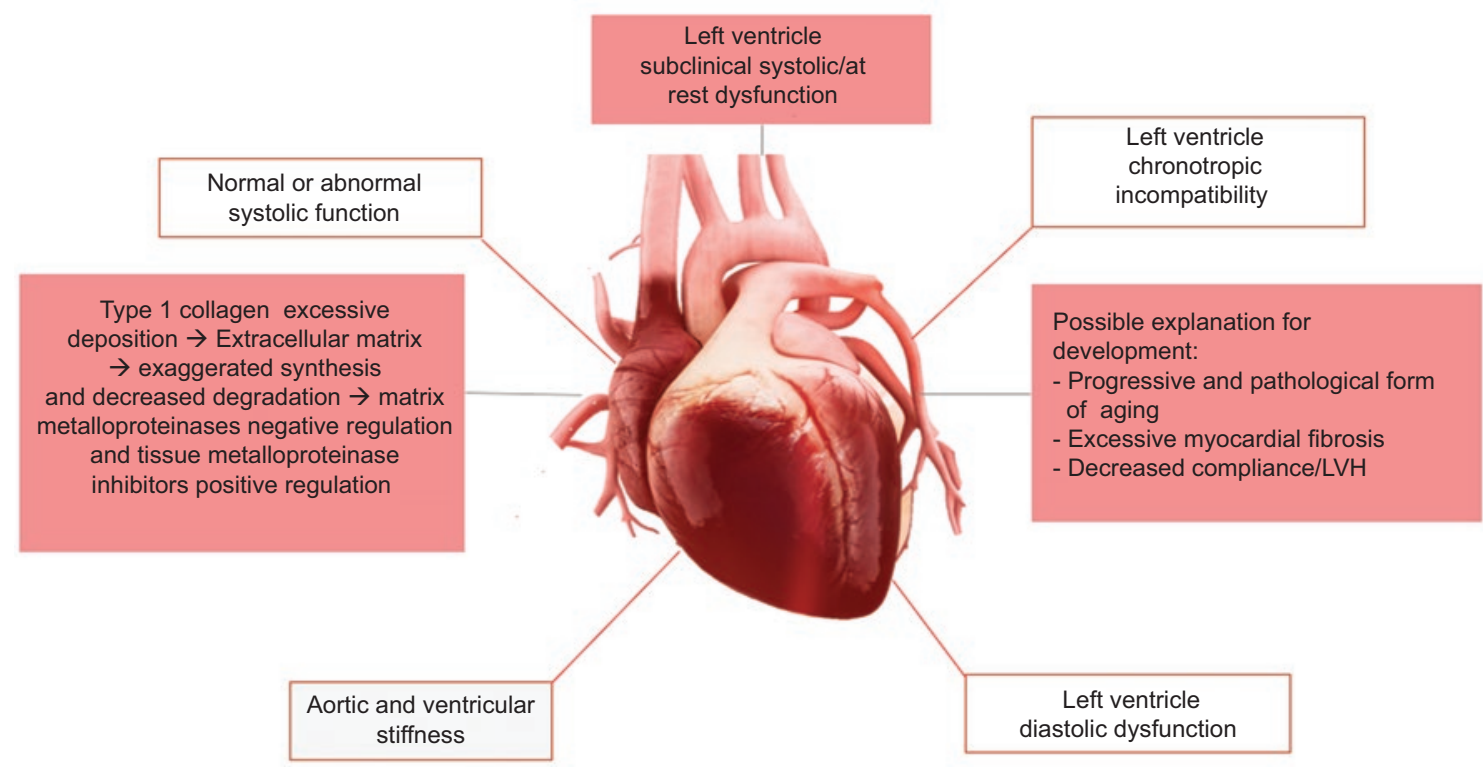

Figure 1. Schematic diagram representing the different pathophysiological mechanisms involved in the development of HFpEF.

was focused on the importance of diastolic dysfunction in HFpEF pathophysiology, multiple unrelated anomalies contribute to the sequence of events that occur in this entity ${ }^{18}$ (Fig. 1). These anomalies include systolic dysfunction at rest and exacerbated by exercise, deteriorated ventricular-vascular coupling, exercise-induced, and flow-mediated abnormal vasodilation, chronotropic incompetence, and pulmonary arterial hypertension.

A study by the Cardiovascular Health Study group in USA demonstrated that biomarkers that reflect myocardial fibrosis such as procollagen type I carboxyl-terminal peptide, collagen type I carboxyl-terminal telopeptide, and procollagen type III amino-terminal peptide are significantly elevated in elderly patients with HFpEF and that these are correlated with HFpEF diagnosis even more than $\mathrm{N}$-terminal pro-brain natriuretic peptide (NT-proBNP) or clinical variables ${ }^{19}$. These results suggest that myocardial fibrosis is an important factor in the development of the HFpEF.

Furthermore, chronotropic incompetence and decreased diastolic reserve during stress have been inversely correlated with the 6-min distance walk. Exercise-induced pulmonary artery systolic pressure elevation $>45 \mathrm{mmHg}$ has been documented to be able to 
Table 2. Heart failure signs and symptoms ordered by frequency/infrequency and specificity or non-specificity (Adapted from Ponikowski et al. ${ }^{4}$ )

\begin{tabular}{|c|c|}
\hline Symptoms & Signs \\
\hline Typical & More specific \\
\hline $\begin{array}{l}\text { Dyspnea } \\
\text { Orthopnea } \\
\text { Paroxysmal nocturnal dyspnea } \\
\text { Reduced exercise capacity } \\
\text { Fatigue, asthenia, longer time of recovery after exercise } \\
\text { Pretibial edema }\end{array}$ & $\begin{array}{l}\text { Elevated jugular venous pressure } \\
\text { Hepatojugular reflux } \\
\text { Third heart sound (S3) } \\
\text { Displaced apical impulse }\end{array}$ \\
\hline Less Typical & Less specific \\
\hline $\begin{array}{l}\text { Nocturnal cough } \\
\text { Wheezing } \\
\text { Sensation of "swelling" } \\
\text { Appetite loss } \\
\text { Confusion (especially in the elderly) } \\
\text { Depression } \\
\text { Palpitations } \\
\text { Dizziness } \\
\text { Syncope }\end{array}$ & $\begin{array}{l}\text { Weight gain ( } 2 \mathrm{~kg} / \mathrm{wk} \text { ) } \\
\text { Weight loss (in advanced HF) } \\
\text { Cachexia } \\
\text { Heart murmur } \\
\text { Peripheral edema (scrotal, ankle, sacrum) } \\
\text { Pulmonary crepitations } \\
\text { Pleural effusion } \\
\text { Tachycardia } \\
\text { Irregular pulse } \\
\text { Tachypnea } \\
\text { Cheyne-Stokes respiration } \\
\text { Hepatomegaly } \\
\text { Ascites } \\
\text { Cold extremities } \\
\text { Oliguria } \\
\text { Narrow pulse pressure }\end{array}$ \\
\hline
\end{tabular}

identify HFpEF with a sensitivity of $96 \%$ and specificity $95 \%{ }^{20-22}$. This type of demonstrated pathophysiological conditions has opened the door to look for new therapeutic forms that can have an effect on survival and quality of life improvement.

\section{Symptoms and quality of life in HFpEF}

HF signs and symptoms are usually nonspecific and do not allow to clearly differentiate HF from other clinical entities (Table 2). In a recent study, where the prevalence of symptoms was compared in patients with HFpEF against HFrEF, clinical differences between HF$\mathrm{pEF} / \mathrm{HFrEF}$ were shown to apparently be related to age and gender rather than to the type of HF per se. Based on the history of symptoms, it was not possible to differentiate HFpEF from $\mathrm{HFrEF}^{23}$.

Patients with HFpEF suffer progressive intolerance to exercise, which significantly alters the physical activity of daily living and causes a deterioration in quality of life mental and social components ${ }^{24}$. In a recent study, hospitalized patients $\geq 60$ years with decompensated HF were found to have physical function broad and marked alterations and high rates of fragility and altered cognition: these irregularities are similar in HFpEF and HFrEF. In addition, depression was common and quality of life was reduced and, remarkably, both were worse in patients with preserved versus reduced systolic function ${ }^{25}$. An effective intervention in this regard is training with exercise, which has been shown to improve emotional state and physical and social dimensions of quality of life, as well as depressive symptoms in comparison with usual care ${ }^{26}$.

\section{Biomarkers in HFpEF}

Natriuretic peptides are essential biomarkers in HF. Their clinical value has been demonstrated in the entire spectrum of LV systolic function, both in HFpEF and $\mathrm{HFbEF/HFrEF}$. Although to a lesser extent, in comparison with patients with a more marked EF reduction, both BNP and NT-proBNP are elevated and are key elements to $\mathrm{HFpEF}$ diagnosis ${ }^{4}$. Negative predictive values are very similar and high (0.94-0.98), either in acute or nonacute cases, but positive predictive values are low in the chronic (0.44-0.57) and acute presentations (0.66$0.67)^{4}$. Therefore, the use of BPN is recommended to rule out HF, but not for diagnosis to be established. In addition, its values increase with other morphological and cardiac function abnormalities (including hypertrophy, fibrosis, and diastolic dysfunction) ${ }^{27}$. There is no clear cutoff point to distinguish HFpEF from HFrEF. BNP and NT-proBNP prognostic properties are maintained regardless of the degree of LV systolic dysfunction ${ }^{28}$. Natriuretic peptide circulating concentrations are 


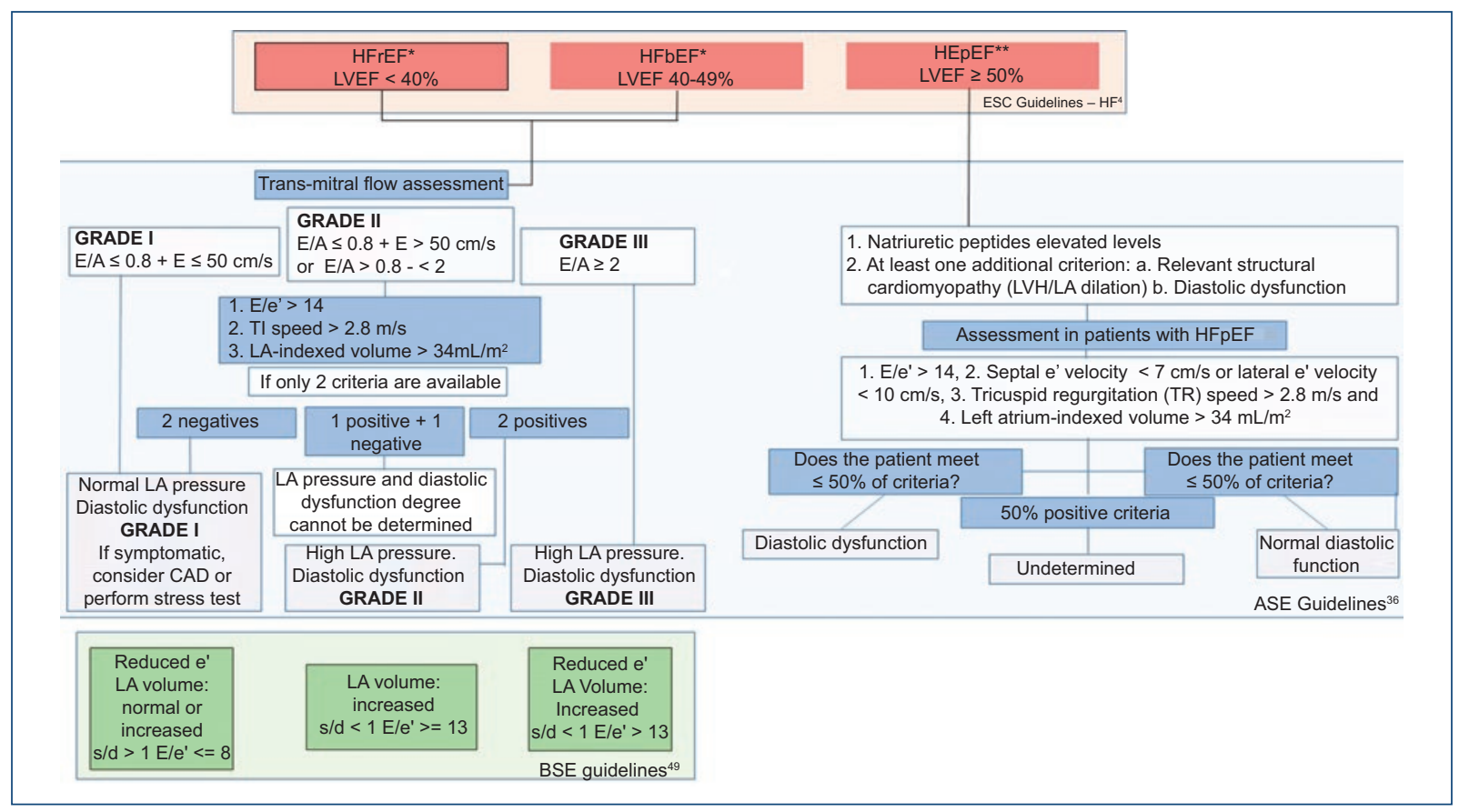

Figure 2. Compilation of recommendations of several societies for the diagnosis of HFpEF and diastolic dysfunction. *In the presence of HF signs and symptoms.

**In the presence of HF signs and symptoms, natriuretic peptides' positive values and structural abnormalities documented by cardiovascular imaging (including diastolic dysfunction). ASE: American Society of Echocardiography; BSE: British Society of Echocardiography; ESC: European Society of Cardiology; LVEF: left ventricular ejection fraction; LA: left atrium; LVH: left ventricular hypertrophy; HFrEF: heart failure with reduced ejection fraction; HFbEF: heart failure with borderline expulsion fraction; HFpEF: heart failure with preserved expulsion fraction.

influenced by several cardiac and extracardiac conditions, as well as by the presence of comorbidities such as atrial fibrillation and kidney disease, which significantly increase plasma values of these peptides ${ }^{29}$.

In addition to natriuretic peptides, patients with HF$\mathrm{pEF}$ have shown significantly higher figures of inflammation and fibrosis biomarkers such as SST2, hs-C-reactive protein (CRP), and cystatin-C, in comparison with patients with HFrEF who have higher values of NT-proBNP and high-sensitivity troponin ${ }^{29}$. The prognostic value for mortality of SST2 has been demonstrated in HFpEF and is comparable to that in HFrEF, especially in acute environments. Gal-3 participates in the processes of cardiovascular inflammation, fibroblast proliferation and fibrosis, and GDF-15 is a marker of cell injury and inflammation. Both circulate at higher concentrations in patients with HFpEF, with diagnostic and prognostic properties for an increased risk of death, and hospitalization associated with $\mathrm{HF}^{30}$.

The activation of proinflammatory pathways is an essential element in HFpEF pathophysiology, where high figures of inflammatory cytokines are observed, including tumor necrosis factor (TNF)- $\alpha$, interleukin (IL)-, IL-6, IL-8, and CRP. Circulating values of TNF- $\alpha$ receptors (TNFR1 and TNFR2) are related to diastolic dysfunction severity and symptoms. There are other participating biomarkers with most pathophysiological mechanisms, including ADM, MR-proADM, von Willebrand factor, or RAAS activation, but their prognostic and diagnostic effect is still under investigation ${ }^{31,32}$.

\section{Imaging studies in HFpEF}

HFpEF clinical diagnosis has to be supported by objective measurements of heart dysfunction at rest or during exercise by echocardiography. The European Society of Cardiology (ESC) recent guidelines define HF$\mathrm{pEF}$ as a LVEF $\geq 50 \%$ and presence of at least one of the following additional criteria: relevant structural heart disease (left ventricular hypertrophy or left atrium enlargement) or diastolic dysfunction ${ }^{4}$. On the other hand, by means of invasive techniques, it is possible to determine hemodynamic parameters at rest to assess filling pressures (pulmonary wedge pressure $\geq 15 \mathrm{mmHg}$ or 
Table 3. Summary of clinical studies on therapeutic interventions in HFpEF (adapted from Ponikowski, et al. ${ }^{4}$ )

\begin{tabular}{|c|c|c|c|c|}
\hline Clinical trial & Intervention & Major inclusion criteria & $\begin{array}{c}\text { Mean } \\
\text { follow-up }\end{array}$ & Primary objectives \\
\hline PEP-CHF 38 & $\begin{array}{l}\text { Perindopril } \\
\text { versus placebo }\end{array}$ & $\begin{array}{l}\text { Segmental mobility index }>1.4 \\
\text { (corresponding to LVEF } 40 \% \text { ), } \\
\text { symptomatic HF treated with diuretic, } \\
\text { diastolic dysfunction for } \\
\text { echocardiography, age }>70 \text { years }\end{array}$ & 2.1 years & $\begin{array}{l}\text { No difference in combined } \\
\text { objective of all-cause mortality } \\
\text { and hospitalizations due to } \\
\text { cardiovascular events ( } 36 \% \text { vs. } \\
37 \%, p=0.35 \text { ) }\end{array}$ \\
\hline I-PRESERVE ${ }^{39}$ & $\begin{array}{l}\text { Irbesartan } \\
\text { versus placebo }\end{array}$ & $\begin{array}{l}\text { LVEF }>45 \% \text {, corroborated NYHA Class } \\
\text { III-IV, or NYHA II with hospitalization in } \\
\text { the past } 6 \text { months due to HF, age }>60 \\
\text { years }\end{array}$ & 4.1 years & $\begin{array}{l}\text { No difference in combined } \\
\text { objective of all-cause mortality } \\
\text { and hospitalization due to HF ( } 24 \\
\text { vs. } 25 \%, p=0.54 \text { ) }\end{array}$ \\
\hline CHARM-Preserved ${ }^{40}$ & $\begin{array}{l}\text { Candesartan } \\
\text { versus placebo }\end{array}$ & $\begin{array}{l}\text { LVEF }>40 \% \text {, NYHA Class II to IV, history } \\
\text { of cardiovascular hospitalization }\end{array}$ & 3 years & $\begin{array}{l}\text { Trend toward combined } \\
\text { cardiovascular mortality reduction } \\
\text { or } 11 \% \text { hospitalization due to } \mathrm{HF} \\
\text { (22\% vs. } 24 \%, p=0.12 \text { not adjusted } \\
\text { and } p=0.051 \text { adjusted) }\end{array}$ \\
\hline Aldo-DHF & $\begin{array}{l}\text { Spironolactone } \\
\text { versus placebo }\end{array}$ & $\begin{array}{l}\text { LVEF }>50 \% \text {, NYHA Class II-III, peak } \mathrm{VO}_{2} \\
<25 \mathrm{~mL} / \mathrm{min} / \mathrm{kg} \text {, diastolic dysfunction on } \\
\text { echocardiogram or atrial fibrillation, age } \\
>50 \text { years }\end{array}$ & 1 years & $\begin{array}{l}\text { E/e } x \text { reduction of }-1.5(p<0.001) \\
\text { No changes in peak } \mathrm{VO}_{2}(p=0.81)\end{array}$ \\
\hline TOPCAT $^{42}$ & $\begin{array}{l}\text { Spironolactone } \\
\text { versus placebo }\end{array}$ & $\begin{array}{l}\text { LVEF }>45 \%,>1 \mathrm{HF} \text { sign, }>1 \mathrm{HF} \\
\text { symptom, recent hospitalization within } \\
\text { past } 12 \text { months or BNP }>100 \mathrm{pg} / \mathrm{mL} \text { or } \\
\text { NT-proBNP }>360 \mathrm{pg} / \mathrm{mL} \text {, age }>50 \text { years }\end{array}$ & 3.3 years & $\begin{array}{l}\text { No difference in combined } \\
\text { objective of cardiovascular death, } \\
\text { aborted cardiac arrest or } \\
\text { hospitalization due to HF (19\% vs. } \\
20 \%, p=0.14 \text { ) }\end{array}$ \\
\hline SENIORS ${ }^{43}$ & $\begin{array}{l}\text { Nebivolol } \\
\text { versus placebo }\end{array}$ & $\begin{array}{l}\text { Confirmed HF as well as hospitalization } \\
\text { within past } 12 \text { months due to HF and/or } \\
\text { LVEF }<35 \% \text { within past } 6 \text { months, } \\
\text { age }>70 \text { years, } 36 \% \text { with LVEF }>35 \%\end{array}$ & 1.8 years & $\begin{array}{l}\text { Reduction in the combined } \\
\text { endpoint of all-cause mortality or } \\
\text { cardiovascular hospitalization of } \\
14 \%(31 \% \text { vs. } 35 \%, p=0.04)\end{array}$ \\
\hline DIG-PEP $P^{44}$ & $\begin{array}{l}\text { Digoxina } \\
\text { versus placebo }\end{array}$ & HF with LVEF > 45\%, sinus rhythm & 3.1 years & $\begin{array}{l}\text { No difference in combined } \\
\text { endpoint of mortality due to HF or } \\
\text { hospitalization due to HF ( } 21 \% \text { vs. } \\
24 \%, p=0.14 \text { ) }\end{array}$ \\
\hline PARAMOUNT ${ }^{45}$ & $\begin{array}{l}\text { Sacubitril/ } \\
\text { valsartan } \\
\text { versus } \\
\text { valsartan }\end{array}$ & $\begin{array}{l}\text { HF with LVEF > } 45 \% \text {, NYHA Class II-III, } \\
\text { NT-proBNP > } 400 \mathrm{pg} / \mathrm{mL}\end{array}$ & 12 weeks & $\begin{array}{l}\text { NT-proBNP reduction; sacubitril/ } \\
\text { valsartan switch index of } 0.77 .65 \% \\
\text { confidence interval, } 0.64-0.92 \\
(p=0.005)\end{array}$ \\
\hline RELAX $X^{46}$ & $\begin{array}{l}\text { Sildenafil } \\
\text { versus placebo }\end{array}$ & $\begin{array}{l}\text { HF with LVEF }>45 \% \text {, NYHA class II-IV, } \\
\text { peak } \mathrm{VO}_{2}<60 \% \text { of reference value, } \\
\text { NT-proBNP }>400 \mathrm{pg} / \mathrm{mL} \text { or elevated } \\
\text { LV-filling pressures }\end{array}$ & 24 weeks & No change in peak $\mathrm{VO}_{2}(p=0.90)$ \\
\hline
\end{tabular}

LV: left ventricle; LVEF: left ventricular ejection fraction; NYHA: New York Heart Association functional class; NT-proBNP: N-terminal pro-B-type natriuretic peptide; HF: heart failure.

left ventricular end-diastolic pressure $\geq 16 \mathrm{mmHg}$ ), followed by evaluation of these parameters during exercise to assess changes in filling pressures, pulmonary systolic blood pressure, heartbeat volume, and cardiac output ${ }^{33,34}$. It is important to highlight that there is controversy regarding echocardiographic indices to diagnose HFpEF: the ESC guidelines do not specify how many diastolic function measurements should be abnormal to establish a diastolic dysfunction diagnosis, but the American Society of Echocardiography, the
European Association of Cardiovascular Imaging and the British Society of Echocardiography include criteria for diastolic dysfunction diagnosis ${ }^{35-37}$. Figure 2 summarizes the recommendations of different societies for the diagnosis of diastolic dysfunction and HFpEF.

\section{HFpEF treatment}

Multiple clinical studies of several groups of drugs, including angiotensin-converting enzyme inhibitors 
(ACEI), angiotensin II receptor antagonists (ARA-II), $\beta$-blockers, and mineralocorticoid antagonists have failed to reduce mortality rates and, in some cases, re-hospitalization rates ${ }^{38-45}$ (Table 3). In a meta-analysis carried out by Shah et al., which included trials such as I-PRESERVE, PEP-CHF, and CHARM-Preserved, no benefit in terms of mortality and re-hospitalizations was identified in the group of drugs that inhibit the renin-angiotensin-aldosterone system such as ACEI and ARA-II ${ }^{46,47}$.

ESC HF current guidelines recommend the use of diuretics, with IB evidence, in patients with $\mathrm{HFpEF}$ and HFrEF for symptom relief if they are congested. In turn, they mention that nebivolol, spironolactone, digoxin, and candesartan might decrease the rehospitalization rate, although they do not state a clear recommendation in this regard ${ }^{4}$.

In the 2017 update, focused on ACC/AHA 2013 guidelines for the treatment of HF, blood pressure control, and the use of diuretics to relieve volume overload symptoms are mentioned, as well as the control of adjacent conditions such as ischemic heart disease and atrial fibrillation ${ }^{48}$. In addition to these general measures and indirect results, no pharmacological treatment has been shown to reduce mortality in HFpEF.

\section{Need for studies in Mexico}

$\mathrm{HF}$ is a serious health problem in Mexico. Population aging and increase in the prevalence of risk factors such as hypertension and dyslipidemia suggest that the number of HFpEF cases is on the rise. However, the lack of regional or national studies magnifies the seriousness of the problem. Currently, there are no prospective studies delimiting epidemiology, clinical presentation, risk factors, treatment instructions, or prognosis for patients with HFpEF in this country ${ }^{49}$.

If we consider that the rates of hypertension, diabetes, obesity, and dyslipidemia are comparable to those in the USA and surpass those of other countries in the world, it is possible that the rate of hospitalizations and death caused by HFpEF is at least similar to that recorded of those countries. Even though the last edition of CENETEC Clinical Practice Guidelines for the treatment of HF already includes the definition of HFpEF, no reference is made to any local data or registry regarding the prognosis of these patients.

This is why the generation of local data aimed at knowing the profile, risk factors, standards of treatment, and prognosis of Mexican patients with HFpEF should be an area to be explored by the Mexican cardiovascular research groups.

\section{Conclusions}

$\mathrm{HF}$ is a growing problem in this country. HFpEF represents a phenotype that involves higher diagnostic difficulties and in which there are no therapeutic options that have been shown to modify prognosis for the future. Carrying out studies in Mexico aimed at knowing the epidemiology, clinical presentation, treatment patterns, and prognosis of this disease is necessary.

\section{Conflicts of interest}

Dr. Diego Araiza has received fees as a member of the Speaker's Bureaus of Novartis, Boehringer Ingelheim and Roche Diagnostics; and a research grant from Novartis.

\section{Ethical disclosure}

Protection of people and animals. The authors declare that no experiments were performed on humans or animals for this study.

Confidentiality of the data. The authors declare that no patient data appear in this article.

Right to privacy and informed consent. The authors declare that no patient data appear in this article.

\section{Acknowledgments}

Arias-Mendoza Maria Alexandra, MD, MBA, FACC - On-Site researcher of the HF with preserved EF trial: PARAGON-HF: Angiotensin Receptor Neprilysin Inhibition in HF With Preserved EF: PARAGON-HF Trial - On-Site researcher of the advanced HF trial: Registrational Study With Omecamtiv Mecarbil/AMG 423 to Treat Chronic HF With Reduced EF (GALACTIC-HF) - On-Site researcher of the trial: Efficacy, Safety, and Tolerability of Serelaxin When Added to Standard Therapy in AHF (RELAX-AHF-2).

\section{References}

1. Shah KS, Xu H, Matsouaka RA, Bhatt DL, Heidenreich PA, Hernández AF, et al. Heart failure with preserved, borderline, and reduced ejection fraction: 5-year outcomes. J Am Coll Cardiol. 2017;70:2476-86.

2. Bui AL, Horwich TB, Fonarow GC. Epidemiology and risk profile of heart failure. Nat Rev Cardiol. 2010;8:30-41.

3. Oktay AA, Rich JD, Shah SJ. The emerging epidemic of heart failure with preserved ejection fraction. Curr Heart Fail Rep. 2013;10:401-10.

4. Ponikowski P, Voors AA, Anker SD, Bueno H, Cleland JGF, Coats AJS, et al. 2016 ESC Guidelines for the diagnosis and treatment of acute and chronic heart failure: The Task Force for the diagnosis and treatment of acute and chronic heart failure of the European Society of Cardiology (ESC) Developed with the special contribution of the Heart Failure Association (HFA) of the ESC. Eur Heart J. 2016;37:2129-200. 
5. Redfield MM. Heart failure with preserved ejection fraction. N Engl J Med. 2016;375:1868-77.

6. OwanTE, Hodge DO, Herges RM, Jacobsen SJ, Roger VL, Redfield MM. Trends in prevalence and outcome of heart failure with preserved ejection fraction. N Engl J Med. 2006;355:251-59.

7. Ciapponi A, Alcaraz A, Calderón M, Matta M, Chaparro M, Soto N, et al. Carga de enfermedad de la insuficiencia cardíaca en América Latina: revisión sistemática y metanálisis. Rev Esp Cardiol. 2016;69:1051-60.

8. Méndez GF, Betancourt L, Galicia-Mora G. The impact of heart failure clinic in the improvement on quality of life of heart failure patients in Mexico. Int J Cardiol. 2007;115:242-43.

9. Bocchi EA, Arias A, Verdejo H, Diez M, Gómez E, Castro P. The reality of heart failure in Latin America. J Am Coll Cardiol. 2013;62:949-58.

10. Hogg K, Swedberg K, McMurray J. Heart failure with preserved left ventricular systolic function: epidemiology, clinical characteristics and prognosis. J Am Coll Cardiol. 2004;43:317-27.

11. Vasan R, Larson MG, Benjamin EJ, Evans JC, Reiss CK, Levy D. Congestive heart failure in subjects with normal versus reduced left ventricular ejection fraction: prevalence and mortality in a population-based cohort. J Am Coll Cardiol. 1999;33:1948-55.

12. KitzmanDW, Little WC, Brubaker PH, Anderson RT, Hundley WG, Marburger CT, et al. Pathophysiological characterization of isolated diastolic heart failure in comparison to systolic heart failure. JAMA. 2002;288:2144-50.

13. Liao L, Jollis GJ, Anstrom KJ, Whellan DJ, Kitzman DW, Aurigemma GP. Costs for heart failure with normal vs reduced ejection fraction. Arch Int Med. 2006;166:112-18.

14. Jacob J, Herrero P, Martín-Sánchez FJ, Pere Llorens, Gil V, Miró O. Prognosis for patients with heart failure with preserved ejection fraction. Rev Esp Cardiol. 2012;65:300-01.

15. Somaratne JB, Berry C, McMurray JJ, Poppe KK, Doughty RN, Whalley GA. The prognostic significance of heart failure with preserved left ventricular ejection fraction: a literature-based meta-analysis. Eur $\mathrm{J}$ Heart Fail. 2009;11:855-62.

16. Meta-analysis Global Group in Chronic Heart Failure (MAGGIC). The survival of patients with heart failure with preserved or reduced left ventricular ejection fraction: an individual patient data meta-analysis. Eur Heart J. 2011:33:1750-57.

17. Tribouilloy C, Rusinaru D, Mahjoub H, Soulière V, Lévy F, Peltier M, et al. Prognosis of heart failure with preserved ejection fraction: a 5 year prospective population-based study. Eur Heart J. 2008;29:339-47.

18. Barry $A B$, Walter JP. Heart failure with preserved ejection fraction: pathophysiology, diagnosis, and treatment. Eur Heart J. 2011;32:670-79.

19. Barasch E, Gottdiener JS, Aurigemma G, Kitzman DW, Han J, Kop WJ, et al. Association between elevated fibrosis markers and heart failure in the elderly: the Cardiovascular Health Study. Circ Heart Fail. 2009;2:303-10.

20. Phan TT, Shivu GN, Abozguia K, Davies C, Nassimizadeh M, Jimenez D, et al. Impaired heart rate recovery and chronotropic incompetence in patients with heart failure with preserved ejection fraction. Circ Heart Fail. 2010;3:29-34

21. Chattopadhyay S, Alamgir MF, Nikitin NP, Rigby AS, Clark AL, Cleland JGF. Lack of diastolic reserve in patients with heart failure and normal ejection fraction. Circ Heart Fail. 2010;3:35-43.

22. Borlaug BA, Nishimura RA, Sorajja P, Lam CSP, Redfield MM. Exercise hemodynamics enhance diagnosis of early heart failure with preserved ejection fraction. Circ Heart Fail. 2010;3:588-95.

23. Steinmann E, Brunner-La Rocca HP, Maeder MT, Kaufmann BA, Pfisterer M, Rickenbacher $P$. Is the clinical presentation of chronic heart failure different in elderly versus younger patients and those with preserved versus reduced ejection fraction? Eur J Intern Med. 2018;57:61-69

24. Coelho R, Ramos S, Prata J, Bettencourt P, Ferreira A Cerqueira-Gomes M. Heart failure and health related quality of life. Clin Pract Epidemiol Ment Health. 2005;1:19.

25. Warraich HJ, Kitzman DW, Whellan DJ, Duncan PW, Mentz RJ, Pastva AM, et al. Physical function, frailty, cognition, depression, and quality of life in hospitalized adults $\geq 60$ years with acute decompensated heart failure with preserved versus reduced ejection fraction. Circ Heart Fail. 2018;11:1-11.

26. Pandey A, Kitzman DW, Brubaker P, Haykowsky MJ, Morgan T, Becton JT, et al. Response to endurance exercise training in older adults with heart failure with preserved or reduced ejection fraction. J Am Geriatr Soc. 2017:65:1698-1704.

27. Tschope C, Kasner M, Westermann D, Gaub R, Poller WC, Schultheiss HP. The role of NT- proBNP in the diagnostics of isolated diastolic dysfunction: correlation with echocardiographic and invasive measurements. Eur Heart J. 2005;26:2277-84.

28. McKelvie RS, Komajda M, McMurray J, Zile M, Ptaszynska A, Donovan M, et al. Baseline plasma NT-proBNP and clinical characteristics: results from the irbesartan in heart failure with preserved ejection fraction trial. J Card Fail. 2010;16:128-34.
29. McCullough PA, Duc P, Omland T, McCord J, Nowak RM, Hollander JE, et al. B-type natriuretic peptide and renal function in the diagnosis of heart failure: an analysis from the Breathing Not Properly Multinational Study. Am J Kidney Dis. 2003:41:571-79.

30. de Boer RA, Lok DJ, Jaarsma T, van der Meer P, Voors AA, Hillege HL, et al. Predictive value of plasma galectin-3 levels in heart failure with reduced and preserved ejection fraction. Ann Med. 2011:43:60-68.

31. Carrasco Sánchez FJ, Aramburu Bodas O, Salamanca Bautista P, Morales Rull JL, Galisteo Almeda L, Páez Rubio MI, et al. Predictive value of serum galectin-3 levels in patients with acute heart failure with preserved ejection fraction. Int J Cardiol. 2013;169:177-82.

32. Chan MM, Santhanakrishnan R, Chong JP, Chen Z, Tai BC, Liew OW, et al. Growth differentiation factor 15 in heart failure with preserved vs. reduced ejection fraction. Eur J Heart Fail. 2016;18:81-88.

33. Erdei T, Smiseth OA, Marino P, Fraser AG. A systematic review of diastolic stress tests in heart failure with preserved ejection fraction, with proposals from the EU-FP7 MEDIA study group. Eur J Heart Fail. 2014;16:1345-61.

34. Donal $E$, Lund LH, Oger E, Reynaud A, Schnell F, Persson $H$, et al. Value of exercise echocardiography in heart failure with preserved ejection fraction: a substudy from the KaRen study. Eur Heart J Cardiovasc Imaging. 2016;17:106-13.

35. Lang RM, Badano LP, Mor Avi V, Afilalo J, Armstrong A, Ernande L, et al. Recommendations for cardiac chamber quantification by echocardiography in adults: an update from the American Society of Echocardiography and the European Association of Cardiovascular Imaging. J Am Soc Echocardiogr. 2015;28:1-39.

36. Nagueh SF, Smiseth OA, Appleton CP, Byrd III BF, Dokainish H, Edvardsen $\mathrm{T}$, et al. Recommendations for the evaluation of left ventricular diastolic function by echocardiography: an update from the American Society of Echocardiography and the European Association of Cardiovascular Imaging. J Am SocEchocardiogr. 2016;29:277-314.

37. Wharton G, Steeds R, Allen J, Phillips H, Jones R, Kanagala P. A minimum dataset for a standard adult transthoracic echocardiogram: a guideline protocol from the British Society of Echocardiography. Echo Res Pract. 2015:2:G9-G24.

38. Cleland JG, Tendera M, Adamus J, Freemantle N, Polonski L, Taylor J, et al. The perindopril in elderly people with chronic heart failure (PEP-CHF) study. Eur Heart J. 2006;27:2338-45.

39. Massie BM, Carson PE, McMurray JJ, Komaida M, McKelvie R, Zile MR, et al. Irbesartan in patients with heart failure and preserved ejection fraction. N Engl J Med. 2008;359:2456-67.

40. Yusuf S, Pfeffer MA, Swedberg K, Granger CB, Held P, McMurray JJ et al. Effects of candesartan in patients with chronic heart failure and preserved left-ventricular ejection fraction: the CHARM-Preserved Trial. Lancet. 2003:362:777-81.

41. Edelmann F, Wachter R, Schmidt AG, Kraigher-Krainer E, Colantonio C, Kamke W, et al. Effect of spironolactone on diastolic function and exercise capacity in patients with heart failure with preserved ejection fraction: the Aldo-DHF randomized controlled trial. JAMA. 2013;309:781-91.

42. Pitt B, Pfeffer MA, Assmann SF, Boineau R, Anand IS, Claggett B, et al. Spironolactone for heart failure with preserved ejection fraction. $\mathrm{N}$ Engl J Med. 2014;370:1383-92.

43. Flather MD, Shibata MC, Coats AJ, Van Veldhuisen DJ, Parkhomenko A, Borbola J, et al. Randomized trial to determine the effect of nebivolol on mortality and cardiovascular hospital admission in elderly patients with heart failure (SENIORS). Eur Heart J. 2005:26:215-25

44. Ahmed A, Rich MW, FlegJL, Zile MR, Young JB, KitzmanDW, et al. Effects of digoxin on morbidity and mortality in diastolic heart failure: the ancillary digitalis investigation group trial. Circulation. 2006;114:397-403.

45. Guazzi M, Vicenzi M, Arena R, Guazzi MD. PDE5 inhibition with sildenafi improves left ventricular diastolic function, cardiac geometry, and clinical status in patients with stable systolic heart failure: results of a 1-year, prospective, randomized, placebo-controlled study. Circ Heart Fail. 2011:4:8-17.

46. Solomon SD, Zile M, Pieske B, Voors A, Shah A, KraigherKrainer E, et al. The angiotensin receptor neprilysin inhibitor LCZ696 in heart failure with preserved ejection fraction: a phase 2 double-blind randomised controlled trial. Lancet. 2012;380:1387-95.

47. Shah RV, Desai AS, Givertz MM. The effect of renin-angiotensin system inhibitors on mortality and heart failure hospitalization in patients with heart failure and preserved ejection fraction: a systematic review and meta-analysis. J Cardiac Fail. 2010;16:260-67.

48. Yancy CW, Jessup M, Bozkurt B, Butler J, Casey DE, Colvin MM, et al. 2017 ACC/AHA/HFSA Focused Update of the 2013 ACCF/AHA Guideline for the Management of Heart Failure: a report of the American College of Cardiology/American Heart Association Task Force on Clinical Practice Guidelines and the Heart Failure Society of America. Circulation. 2017:136:e137-e161.

49. T Matthew, Steeds R, Jones R, Kanagala P, Lloyd G, Knight D, et al. A guideline protocol for the echocardiographic assessment of diastolic function - a protocol of the British Society of Echocardiography. Echo Res Pract. 2013;5-6. 